\title{
IMPLEMENTASI METODE SELF DIRECTED LEARNING DAN DISKUSI KELOMPOK KECIL DALAM RANGKA MENINGKATKAN KOMPETENSI MENERAPKAN KONSEP MODEL KEPERAWATAN DALAM BERBAGAI SITUASI PADA MATA AJAR ILMU KEPERAWATAN DASAR II
}

\author{
Insiyah \\ Kementerian Kesehatan Politeknik Kesehatan Surakarta Jurusan Keperawatan
}

\begin{abstract}
Self Directed Learning, Small Group Discussion, Basic Nursing Science II. Basic Nursing Science II, is a subject for nursing students in Diploma IV This is a new subject based on curriculum 2014 containing of important concepts such as nursing theory that sometimes it is difficult for student to learn. Commonly students encounter difficulties in this subject so that they are not interested in it. They think that this subject is difficult to be understood because it contains of concepts. The aims of this research is to identify the success of learning methods by using self directed learning and small group discussion in order to increase student ability to achieve competence in application of conceptual nursing model in any situation. This research is Classroom Action Rersearch design. The result show that self directed learning and small group discussion methods are the learning methods that can increase student activity in learning process and improve student ability to achieve competence in application of conceptual nursing model in any situation.
\end{abstract}

Key Words: Self Directed Learning, Small Group Discussion, Basic Nursing Science II

\begin{abstract}
Abstrak: Self Directed Learning, Diskusi Kelompok Kecil, Ilmu Keperawatan Dasar II. Mata ajar Ilmu Keperawatan Dasar II merupakan salah satu mata ajar yang diberikan di Prodi D IV Keperawatan merupakan mata ajar baru menurut kurikulum 2014. Pada umumnya mahasiswa mengalami kesulitan pada mata ajar ini karena menganggap pelajaran konsep sulit untuk dipahami sehingga pada akhirnya membosankan. Penelitian ini bertujuan untuk mengetahui keberhasilan metode pembelajaran Self Directed Learning dan diskusi kelompok kecil dalam meningkatkan kemampuan mahasiswa mencapai kompetensi menerapkan model konsep konseptual keperawatan dalam berbagai situasi. Penelitian ini menggunakan desain Classroom Action Rersearch (Penelitian Tindakan Kelas) yaitu suatu penelitian yang dilakukan oleh seorang guru/ dosen di dalam kelasnya sendiri melalui refleksi diri, dengan tujuan untuk memperbaiki kinerjanya, sehingga dapat meningkatkan hasil belajar mahasiswa. Hasil penelitian menunjukkan bahwa metode pembelajaran Self Directed Learning dan diskusi kelompok kecil merupakan metode yang dapat meningkatkan keaktifan mahasiswa dan dapat meningkatkan kemampuan mahasiswa mencapai kompetensi dasar menerapkan konsep model keperawatan dalam berbagai situasi.
\end{abstract}


Kata Kunci : Self Directed Learning, Diskusi Kelompok Kecil, Ilmu Keperawatan Dasar II

\section{PENDAHULUAN}

Menjadi seorang perawat dituntut untuk memiliki kemampuan dalam pengambilan keputusan yang tepat dan didukung oleh kemampuan dalam memahami konsep-konsep yang terkait dengan pelayanan keperawatan. Potter, P.A. dan Perry, A.G. (1999) mengatakan bahwa seorang perawat memiliki tanggung jawab untuk mengambil keputusan klinis yang akurat dan sesuai. Dalam membantu pasien untuk memelihara, memperoleh dan meningkatkan kesehatannya, seorang perawat harus mampu berfikir kritis dalam menyelesaikan masalah dan mencari solusi yang baik. Berbagai reaksi pasien akan ditemui oleh seorang perawat tergantung dari mana pasien berasal, pengalaman yang diperoleh sebelumnya, maupun kondisi sakit yang diderita oleh pasien. Institusi pendidikan di dunia telah membuat pendekatan yang inovatif dalam pembelajaran. Beberapa telah menerapkan Problem Based Lerning dan berpindah dari teacher-based curriculum. Problem Based Learning, Active Learning, Student-Centered Learning mengidentifikasikan adanya pergeseran fungsi kekuatan dosen kepada mahasiswa dalam proses pembelajaran (Hesson, M. \& Shad, K.F., 2007). Dalam pelaksanaannya, mata ajar Ilmu Keperawatan Dasar II yang merupakan salah satu mata ajar yang diberikan di Prodi D IV Keperawatan menemui masalah karena selain mata ajar ini diberikan di semester I yang berarti diperuntukkan bagi mahasiswa baru, mata ajar ini berisikan konsep-konsep penting yang harus dipelajari mahasiswa perawat.
Pada umumnya mahasiswa mengalami kesulitan pada mata ajar ini karena menganggap pelajaran konsep sulit untuk dipahami sehingga pada akhirnya membosankan. Sebagai dosen mata kuliah ini tentu saja memiliki suatu tantangan karena selain menghadapi mahasiswa di masa transisi sekolah menengah kemudian menjadi mahasiswa, mereka masih harus beradaptasi dengan lingkungan di sekitarnya baik yang bersifat fisik maupun sosial. Lingkungan yang baru seperti teman yang baru, dosen baru dan metode yang berbeda merupakan masalah tersendiri bagi mahasiswa. Hal lain yang menjadi masalah adalah bahwa mata ajar ini merupakan mata ajar dasar untuk menjadi perawat karena di dalamnya berisi tentang berbagai materi dasar keperawatan, sementara mahasiswa belum memiliki pengalaman yang cukup terkait dengan situasi nyata pasien. Dari latar belakang di atas maka dapat diidentifikasi masalah sebagai berikut:mahasiswa merasa jenuh / bosan terhadap proses pembelajaran, partisipasi mahasiswa dalam pembelajaran masih minimal, mahasiswa kurang mampu berpendapat dan sulit menerima perbedaan pendapat, mahasiswa kurang menguasai materi

Berdasarkan identifikasi maka dapat dianalisis beberapa masalah yang mempengaruhi tingkat ketuntasan mahasiswa antara lain:penggunaan metode yang kurang bervariasi, pemberian petunjuk pengerjaan tugas yang tidak jelas, penggunaan metode kurang tepat sehingga tidak menarik bagi mahasiswa. 


\section{METODE PENELITIAN}

Penelitian ini menggunakan desain Classroom Action Rersearch (Penelitian Tindakan Kelas) yaitu suatu penelitian yang dilakukan oleh seorang guru / dosen di dalam kelasnya sendiri melalui refleksi diri, dengan tujuan untuk memperbaiki kinerjanya, sehingga hasil belajar mahasiswa menjadi meningkat (Wardani, Wihardit, dan Nasution, 2006). Subjek pada penelitian ini adalah semua mahasiswa D IV Keperawatan Politeknik Kesehatan Surakarta Semester I Kelas I A Prodi D IV Keperawatan Tahun Akademik 2015/2016 yang mengikuti pembelajaran mata ajar Ilmu Keperawatan Dasar II sejumlah 47 mahasiswa dengan karakteristik memiliki kemampuan rata-rata, tingkat keaktifan mahasiswa masih kurang merata dan hanya menonjol pada beberapa mahasiswa tertentu. Alat pengumpul data dalam penelitian ini berupa lembar observasi dan interprestasi secara simultan mengenai proses dan hasil tindakan dosen selama proses pembelajaran, Observasi dilakukan tidak hanya pada dosen yang mengajar tetapi juga pada respon mahasiswa terhadap apa yang terjadi selama proses pembelajaran. Dalam hal diskusimkelompok kecil maka akan diobservasi tentang: keaktifan mahasiswa, ketertarikan mahasiswa terhadap materi, kemampuan mengambil keputusan, kerjasama dalam kelompok. Pada tahap refleksi peniliti bersama tim dosen mendiskusikan hasil observasi selama proses pembelajaran dan hasil refleksi. Adapaun Siklus ke II dilakukan dalam rangka memperbaiki siklus I dengan langkah-langkah yang sama dengan siklus I tetapi dengan perubahan pada berbagai hal yang perlu diperbaiki.

\section{HASIL PENELITIAN}

\begin{tabular}{llr}
\multicolumn{1}{c}{ Pada } & saat & pelaksanaan \\
pembelajaran & siklus I & observer \\
melakukan & pengamatan & terhadap
\end{tabular} proses pembelajaran baik bagi mahasiswa maupun dosen dengan mengisi lembar observasi dan mencatat hal-hal yang ditemukan selama proses pembelajaran berlangsung. Pada tahap perencanaan pengamat melihat kesiapan dosen dalam memberikan perkuliahan dengan melihat rencana pembelajaran semester dan rencana pembelajaran (RPS dan RP) yang telah dibuat oleh dosen dan komponenkomponen yang harus ada di dalamnya, dan mengecek waktu pembelajaran sesuai jadwal. Dari hasil pengamatan terhadap dosen pada saat pelaksanaan pembelajaran mulai dari awal sampai akhir pembelajaran diperoleh data bahwa dosen telah menyampaikan tujuan pembelajaran tetapi belum secara lengkap menjelaskan tentang self directed learning yang harus dilaksanakan oleh mahasiswa dan juga melibatkan dosen sebagai fasilitator. Apersepsi telah dilakukan oleh dosen terhadap materi ajar yang telah diberikan dalam modul pada awal semester. Di dalam apersepsi dapat diobservasi bahwa hanya sebagian mahasiswa tertarik untuk menjawab pertanyaan dari dosen, masih ada mahasiswa yang tampak diam dan sibuk sendiri. Sebagian mahasiswa lupa tidak membawa modul dan mengaku belum siap dengan materi karena belum membaca modul yang diberikan. Selain menggunakan modul yang sudah ada dosen menggunaakan sarana audiovisual untuk memperjelas konsep tentang konsep model teori 
keperawatan. Dalam rangka meningkatkan partisipasi mahasiswa dosen melakukan pembagian kelompok-kelompok kecil masingmasing 4-5 orang, dengan persetujuan mahasiswa memilih sendiri anggota kelompoknya, dan membagikan sebuah teori keperawatan. Dosen menjelaskan kepada mahasiswa bahwa selain mereka harus bekerja di dalam kelompok kecil, hasil diskusi kelompok kecil harus juga dipresentasikan di depan kelas. Dosen telah membantu dengan baik kesulitan mahasiswa selama proses berlangsung dengan memberikan penjelasan pada setiap pertanyaan yang diajukan kelompok, memberikan contoh yang relevan pada konsep yang sedang dibicarakan. Ketika masih ada ketidakjelasan dari mahasiswa, dosen menyampaikan kepada mahasiswa bahwa masih ada lagi pertemuan berikutnya untuk mempelajari konsep lebih mendalam. Penilaian pencapaian tujuan pembelajaran secara individual belum diberikan pada siklus I karena dosen memberikan kesempatan kepada mahasiswa untuk belajar lebih giat lagi dan kembali melihat tujuan apa yang akan mahasiswa capai dalam pembelajaran. Berdasarkan evaluasi tersebut, dosen menyampaikan rencana tindak lanjut untuk kegiatan pembelajaran pada pertemuan selanjutnya dalam rangka pencapaian kompetensi yang sama. Di akhir pembelajaran dosen telah memberikan petunjuk kepada mahasiswa untuk membaca modul dan referensi terlebih dahulu ataupun memenuhi apa yang mahasiswa ingin capai sebagaimana tersebut dalam rencana pelaksanaan pembelajaran dalam rangka memperbaiki pembelajaran pada siklus ke II. Dosen dinilai oleh sejawat memiliki kompetensi dengan nilai 4,4 yang artinya dosen telah memberikan pembelajaran dengan baik. Selain telah dilakukan pengamatan terhadap dosen, berikut ini merupakan hasil pengamatan terhadap mahasiswa. Dari pengamatan terhadap diskusi kelompok mahasiswa dalam rangka memahami konsep model keperawatan dan bagaimana aplikasinya menunjukkan hasil yang belum maksimal. Berdasarkan penilaian menggunakan pedoman penilaian presentasi kelompok, mahasiswa dinilai dalam 3 kategori penilaian antara lain : penguasaan materi secara keseluruhan, presentasi konsep, dan daya tarik komunikasi. secara berkelompok mahasiswa telah tuntas pada kompetensi menerapkan konsep model keperawatan dengan menghadirkan contoh-contoh riil yang sesuai dengan konsep yang dipelajari, dengan pencapaian masing-masing kelompok antara $70 \%$ samapai $85 \%$ dengan ratarata pencapaian kelas $78 \%$. Meskipun mahasiswa telah mencapai ketuntasan pada siklus I, namun berdasarkan pengamatan terhadap proses diskusi kecil dalam kelompok terdapat ketimpangan di mana belum semua mahasiswa berpartisipasi secara aktif dalam kerja timnya dan partisipasi tampak menonjol pada beberapa mahasiswa. tingkat partisipasi mahasiswa relatif merata dimana $19 \%$ mahasiswa sungguh-sungguh berpartisipasi dalam kelompok kecil dengan menyampaikan pemikirannya terhadap pertanyaan yang diajukan dan secara aktif mendengarkan teman lain yang sedang berbicara dalam diskusi yang berlangsung. Sebanyak 49\% lainnya lebih menunjukkan partisipasi dengan cara menyampaikan pemikirannya terhadap pertanyaan 
yang diajukan, dan sisanya yang $32 \%$ tidak ikut memikirkan jawaban yang diajukan tetapi aktif mendengarkan jalannya diskusi.

Dalam hal kerja tim, sebagian besar mahasiswa $34 \%$ dapat mengkomunikasikan isi dari topik yang didiskusikan kelompok, $49 \%$ mahasiswa bahkan telah secara jelas dan kreatif mengkomunikasikan topik yang didiskusikan. Masih ada 17\% mahasiswa yang tidak ikut mengkomunikasikan topik yang didiskusikan akan tetapi masih ikut membantu jalannya diskusi, dan tidak ada mahasiswa yang sama sekali tidak berpartisipasi dalam diskusi kelompok kecil.

Pada akhir pembelajaran dosen memberikan kesempatan kepada mahasiswa tentang apa yang sudah dilakukan mahasiswa dan belum dilakukan oleh mahasiswa. Sebagai tambahan data terhadap pengamatan mahasiswa berdasarkan catatan khusus dosen dan pengamat antara lain: keaktifan mahasiswa dalam diskusi kelompok masih belum merata, masih dijumpai ketika ada mahasiswa yang tampak aktif membicarakan topik yang dimaksud, ada mahasiswa yang lain dalam kelompok yang sama tampak sibuk sendiri dan tidak secara aktif mengikuti jalannya diskusi. Berdasarkan refleksi mahasiswa melalui pengisian kuestioner diperoleh data sbb: mahasiswa mulai jelas dengan konsep yang diajarkan dengan melalui diskusi kecil tentang sebuah kasus. Dengan adanya self directed learning memudahkan mahasiswa untuk berfikir seolah apa yang dikasus dapat dialami oleh mahasiswa dan bukan hanya angan-angan saja. Mahasiswa merasa butuh untuk memperdalam pemahamannya dengan terlebih dulu memahami konsep dan membandingkan dengan hal-hal yang pernah dilihat atau dialaminya. Dari refleksi mahasiswa juga ditemukan data bahwa bahan ajar yang berupa hand out dan modul, atau referensi lain belum selesai dibaca dan sebagian besar mahasiswa tidak membawa modul atau referensi lain dalam proses pembelajaran. Peniliti bersama sejawat mendiskusikan hasil observasi selama proses pembelajaran. Hasil refleksi digunakan untuk memperbaiki pelaksanaan pembelajaran pada siklus II.

Pada siklus II ini beberapa perbaikan dilakukan berdasarkan refleksi pada siklus I. Bersama sejawat peneliti berkolaborasi merencanakan kembali penerapan metode pembelajaran dalam diskusi kelompok kecil dan Self Directed Learning dan melihat kelemahan-kelemahan dalam meningkatkan proses pembelajaran khususnya dalam penguasaan konsep model keperawatan dan meningkatkan keaktifan mahasiswa secara merata. Dalam rangka memberikan informasi tentang hal apa saja yang harus ditampilkan oleh mahasiswa maka dosen membagikan pedoman penilaian pencapaian kompetensi mahasiswa yang sebelumnya pada siklus I tidak dibagikan kepada mahasiswa. Peneliti melengkapi instrumen penelitian yang terdiri dari rencana pembelajaran(RP) Mata Ajar Ilmu Keperawatan Dasar II sebagai guide dosen dalam melaksanakan pembelajaran dan petunjuk penugasan mahasiswa dalam kontrak belajar. Perlengkapan lain yang disiapkan antara lain: lembar observasi yang digunakan sebagai pedoman pangamatan terhadap dosen selama proses pembelajaran berlangsung, lembar observasi atau catatan pengamat 
terhadap aktifitas mahasiswa selama proses pembelajaran berlangsung, dan kuesioner mahasiswa yang berisi pertanyaan terbuka yang harus dijawab oleh mahasiswa terkait dengan proses pembelajaran juga masih digunakan dalam siklus II.

Beberapa kelemahan dosen pada siklus I diperbaiki dan keaktifan mahasiswa ditingkatkan. Dosen diamati oleh teman sejawat terkait dengan proses pembelajaran yang telah direncanakan dalam rencana pembelajaran. Partisipasi mahasiswa selama proses pembelajaran dilaksanakan diamati dan dicatat sebagai data untuk dianalisis. Kemampuan mahasiswa dalam mencapai kompetensi dasar sebagaimana tercantum dalam rencana pembelajaran (RP) dievaluasi berdasarkan pedoman penilaian yang telah dipersiapkan sebelumnya dan juga telah dibagikan kepada mahasiswa. Pada akhir pembelajaran dosen membagikan kuestioner yang berisi pertanyaan terbuka untuk dijawab mahasiswa melalui refleksi diri dan hasil evaluasinya terhadap proses pembelajaran yang telah berlangsung.

Pada saat pelaksanaan pembelajaran siklus II observer melakukan pengamatan terhadap proses pembelajaran baik bagi mahasiswa maupun dosen dengan instrumen yang telah disiapkan. Dari hasil pengamatan terhadap dosen diperoleh data bahwa dosen masih mempertahankan aspek-aspek penting dalam pembelajaran dan telah dilakukan pada siklus sebelumnya dan ditambahkan data menurut catatan pengamat sbb: dosen telah menyampaikan tujuan pembelajaran sesuai dengan rencana pembelajaran (RP) yang telah dibuat dan menyebutkan secara terinci poin-poin yang harus diidentifikasi. Apersepsi telah dilakukan oleh dosen terhadap materi ajar yang telah diberikan dalam modul pada awal semester. Di dalam apersepsi dapat diobservasi bahwa sebagian besar mahasiswa tertarik untuk menjawab pertanyaan dari dosen. Secara serentak mahasiswa menyatakan telah siap dengan pembelajarn dan mencapai tujuan yang mereka inginkan. Berdasarkan pemahaman mahasiswa terhadap konsep keperawatan yang telah diperoleh dari membaca materi ajar, mahasiswa diberikan tugas kelompok untuk memberikan penilaian terhadap kelompok mahasiswa yang mempresentasikan hasil diskusi kecilnya. Aktifitas dosen dalam kelompok dapat pula diamati dimana dosen telah membantu dengan baik kesulitan mahasiswa selama proses berlangsung dengan memberikan penjelasan pada setiap pertanyaan yang diajukan kelompok. Dosen mata ajar dan sejawat yang terdiri dari 2 orang berbagi tugas dalam membantu mahasiswa selama proses diskusi serta melakukan pengamatan.

Dari pengamatan terhadap mahasiswa melalui catatan pengamat dan dosen, refleksi mahasiswa, dan tool penilaian terhadap pencapaian kompetensi dasar menerapkan konsep model teori keperawatan, mahasiswa telah mampu memberikan contohcontoh aplikasi masing-masing teori dihubungkan dengan kehidupan seharihari dalam berbagai situasi. Penilaian terhadap hasil kerja mahasiswa secara berkelompok pada siklus II menunjukkan bahwa mahasiswa telah mencapai ketuntasan dalam mencapai kompetensi penerapan konsep model keperawatan. Masing-masing 
kelompok mencapai skor berkisar antara $80 \%$ sampai $95 \%$ dengan ratarata pencapaian kelas $84,40 \%$. Berdasarkan pengamatan terhadap proses diskusi dalam kelompok kecil sebagian besar mahasiswa berpartisipasi secara aktif dalam kerja timnya dan partisipasi tampak ditunjukkan oleh hampir pada semua mahasiswa. Adapun pengamatan kerja tim dalam diskusi kecil dengan menggunakan pedoman penilaian keaktifan individu dalam diskusi kelompok kecil menunjukkan bahwa partisipasi mahasiswa relatif meningkat dimana $26 \%$ mahasiswa sungguhsungguh berpartisipasi dalam kelompok kecil dengan menyampaikan pemikirannya terhadap pertanyaan yang diajukan dan secara aktif mendengarkan teman lain yang sedang berbicara dalam diskusi yang berlangsung. Sebanyak 55\% lainnya lebih menunjukkan partisipasi dengan cara menyampaikan pemikirannya terhadap pertanyaan yang diajukan, dan sisanya yang $19 \%$ tidak ikut memikirkan jawaban yang diajukan tetapi aktif mendengarkan jalannya diskusi. Tidak ada mahasiswa yang sama sekali tidak berpartisipasi dalam kelompok diskusi.

Dalam hal kerja tim, sebagian besar mahasiswa $36 \%$ dapat mengkomunikasikan isi dari topik yang didiskusikan kelompok dan persentase ini melebihi persentase pada siklus I, sedangkan mahasiswa yang telah secara jelas dan kreatif mengkomunikasikan topik yang didiskusikan hampir sepertiga dari jumlah peserta didik yaitu $55 \%$. Jumlah mahasiswa yang hanya ikut andil saja tanpa mengkomunikasikan topik yang dimaksud yaitu $9 \%$ saja dan tidak ada mahasiswa yang sama sekali tidak berpartisipasi dalam diskusi kelompok kecil. Pada akhir pembelajaran dosen memberikan kesempatan kepada mahasiswa tentang apa yang sudah dilakukan mahasiswa dan belum dilakukan oleh mahasiswa. Sebagai tambahan data terhadap pengamatan mahasiswa berdasarkan catatan khusus dosen dan pengamat antara lain: keaktifan mahasiswa dalam diskusi kelompok sudah merata, dan kelas tampak hidup. Berdasarkan refleksi mahasiswa melalui angket diperoleh data sbb: mahasiswa semakin jelas dengan konsep yang diajarkan dengan melalui diskusi kelompok kecil dengan self directed learning. Dari refleksi mahasiswa juga ditemukan data bahwa bahan ajar yang berupa hand out dan modul, atau referensi lain yang telah selesai dibaca membantu mahasiswa mengidentifikasi konsep yang dimaksud. Pembagian kelas menjadi kelompok kecil yang terdiri dari 4-5 orang membuat mahasiswa merasa lebih nyaman untuk mengutarakan pendapatnya dan merasa memiliki waktu yang cukup untuk ikut berpartisipasi dalam kelompoknya. Dosen yang selalu memotivasi mahasiswa untuk selalu percaya diri dan bersikap fleksible juga sangat membantu mahasiswa dalam mencapai tujuan yang dimaksudkan.

\section{PEMBAHASAN}

Perbaikan pembelajaran pada siklus I difokuskan pada pelaksanaan pembelajaran dengan menggunakan metode diskusi kelompok kecil dan self directed learning. Langkah-langkah perbaikan telah dilakukan dengan melakukan evaluasi terhadap rencana pelaksanaan pembelajaran yaitu RPS dan RP. Pada tahap perencanaan terdapat beberapa kelemahan di mana 
pada kriteria penilaian di RPS telah lengkap akan tetapi pedoman penilaian terhadap mahasiwa tidak ikut diserahkan pada tahap pertama penjelasan rencana pelaksanaan pembelajaran. Kegiatan mahasiswa juga belum secara lengkap dijelaskan pada rencana pelaksanaan pembelajaran tersebut. Design penugasan yang baik harus didefinisikan dengan jelas, disertai petunjuk yang terstruktur dan jelas sebagai dasar mahasiswa memulai bekerja. Adanya kelemahan ini berdampak pada pelaksanaan pembelajaran di mana beberapa mahasiwa tidak siap terlibat secara aktif dalam pembelajaran karena tidak memiliki bahan ajar atau referensi sebagai acuan dalam melaksanakan tugas kelompok. Williams, K., \& Williams, C. (2011) mengatakan bahwa ada lima hal yang dapat memberikan dampak pada mahasiswa untuk termotivasi belajar antara lain: mahasiswa itu sendiri, dosen, isi yang dipelajari, metode atau proses yang digunakan dan lingkungan. O'Shea, E.(2003) menyatakan bahwa self directed learning akan meningkatkan kepercayaan diri, kemandirian, motivasi serta mengembangkan ketrampilan mahasiswa dalam belajar dan berlatih.

Penugasan dalam bentuk diskusi kelompok kecil ini dilaksanakn dalam rangka memahami konsep model keperawatan dan bagaimana penerapannya dalam situasi yang sesuai. Dalam hal pemilihan kelompok, mahasiswa dipersilahkan untuk memilih kelompoknya sendiri dan cara ini cukup memuaskan mahasiwa. Pemilihan anggota tim oleh mahasiswa sendiri didasarkan pada ketertarikan yang sama sehingga akan memudahkan mereka untuk bekerjasama. Jika kepentingan pembelajaran untuk sekedar berdiskusi maka kelompok bisa beranggotakan lebih banyak sekitar 10 orang, akan tetapi jika kelompok tersebut dibentuk dalam rangka menyelesaikan sebuah penugasan maka memerlukan kelompok kecil antara 4-6 orang untuk mengefektifkan kerja tim. Diskusi dalam kelompok yang kecil akan memberikan keuntungan antara lain; mahasiswa akan lebih nyaman berpartisipasi dalam kelompoknya, memberikan kesempatan yang lebih untuk berpartisipasi, interaksi antar mahasiswa lebih banyak dan tidak hanya tergantung dari instruktor dan mahasiswa, dan mahasiswa bisa belajar membangun kerjasama dan kepemimpinan dalam situasi tertentu. Dalam kelompok kecil terjadi brain storming, diskusi Self Directed Learning, dan mengkritisi satu sama lain dalam kelompok.

Dalam konteks student-center learning, mahasiswa memiliki tanggung jawab penuh terhadap pembelajarannya dan partisipasinya dalam pembelajaran sangatlah penting, pengetahuan dikonstruksikan oleh mahasiswa dan dosen lebih sebagai fasilitator (Kemler, 1997). Dalam hal penerapan self directed learning sebagai salah satu metode pembelajaran, kemampuan mahasiswa sangat bervariasi dalam menetapkan tujuan dan mengembangkan kontrak belajar, memonitor proses mahasiswa sendiri dalam belajar. Inisiatif mahasiswa tampak pada bagaimana kelompok menyajikan setiap presentasi yang diberikan, dan kesadaran untuk berkonsultasi dengan dosen baik secara individu maupun kelompok. Sebagian kecil mahasiswa berkonsultasi atas kesadaran sendiri baik datang ke dosen 
maupun melalui telepon atau sms ketika menemukan kesulitan dalam pembelajaran mandiri maupun kelompok. Kesediaan dosen untuk melayani mahasiswa secara fleksible juga membantu dalam metode pembelajaran ini. Namun demikian keberhasilan self directed learning sangat dipengaruhi harapan mahasiswa tentang suatu topic yang sedang dipelajari dan dosen sebagai fasilitator.

Pada perbaikan tahap pertama mahasiswa telah mampu menguasai konsep-konsep dalam teori keperawatan. Hal ini dapat dilihat pada pencapaian hasil kerja kelompok. Pencapaian ini dirasakan belum mewakili pencapaian mahasiswa secara individu karena pada observasi tentang partisipasi individu masih ditemukan mahasiswa yang hanya duduk diam mendengarkan jalannya diskusi. Hal yang lain yang diobservasi dan menjadi catatan dosen adalah penataan tempat duduk yang cukup semrawut di mana duduk berjajar dan tidak secara optimal kontak satu sama lain dalam kelompok juga memicu tidak meratanya interaksi antar kelompok.

Pada akhir pembelajaran dosen melakukan refleksi dengan melibatkan mahasiswa serta melaksanakan tindak lanjut yang harus dilakukan oleh mahasiswa terhadap apa yang telah dicapai dan tugas tentang apa yang harus dipersiapkan untuk pertemuan selanjutnya sebagai bagian dari remedial atau pengkayaan. Dosen juga memberikan kesempatan kepada mahasiswa untuk bernegosiasi tentang apa yang harus dilaksanakan dalam rangka persiapan pembelajaran berikutnya.

Pada siklus II mahasiswa telah siap dengan bahan ajar dan referensi masing-masing untuk berdiskusi kelompok untuk mengidentifikasi konsep. Jumlah 4-5 mahasiswa dalam 1 kelompok dirasakan cukup oleh mahasiswa dan mahasiswa memilih sendiri anggota kelompoknya. Pemilihan anggota kelompok yang didasarkan pada minat yang sama akan memudahkan kerja sama. Dari hasil refleksi dan pengamatan dapat diringkas adanya data sebagai berikut: tingkat keaktifan individu meningkat dan bisa diobservasi dari tingkat partisipasi mahasiswa yang berpartisipasi secara aktif baik memberi jawaban, bertanya dan mendengarkan teman berpendapat. Dalam hal kerjasama meningkat dari yang tadinya hanya mendengarkan saja menjadi ikut andil berbicara dalam mengkomunikasikan topik yang dibicaraka. Peningkatan ini disebabkan adanya keefektifan dari kelompok kecil dan adanya motivasi mahasiswa bahwa sesuatu harus dicapai berdasarkan pedoman penilaian yang telah dibagikan kepada mahasiswa.

\section{KESIMPULAN DAN SARAN}

Metode pembelajaran diskusi kelompok kecil merupakan salah satu metode yang dapat meningkatkan kemampuan mahasiswa mencapai kompetensi dasar menerapkan konsep dasar keperawatan dalam berbagi situasi. Metode diskusi kelompok kecil merupakan salah satu metode yang dapat meningkatkan keaktifan mahasiswa dalam pembelajaran Ilmu Keperawatan Dasar II . Metode pembelajaran self directed learning merupakan salah satu metode yang dapat meningkatkan kemampuan mahasiswa mencapai kompetensi dasar menerapkan konsep dasar keperawatan dalam berbagai situasi, metode pembelajaran self directed learning 
merupakan salah satu metode yang dapat meningkatkan keaktifan mahasiswa dalam pembelajaran Ilmu Keperawatan Dasar II. Metode pembelajaran diskusi kelompok kecil dan self directed learning dapat diterapkan dalam rangka membantu mahasiswa untuk berpartisipasi secara aktif dalam rangka mencapai kompetensi yang dimaksud. Dosen sebaiknya membiasakan diri untuk melakukan self evaluasi sebagai role model dalam rangka memberikan contoh bagi mahasiswa untuk memahami kekurangan dan meningkatkan perannya sebagai fasilitator dalam pembelajaran.

\section{DAFTAR RUJUKAN}

Hesson, M. \& Shad, K.F. (2007), “A student-centered learning model," American Journal of Applied Sciences, 628-636

Kember, D. (1997). A reconceptualisation of the research into university academics conceptions of teaching. Learning and Instruction 7 ( 3 ).

O'Shea, E.(2003). Self-directed learning in nurse education: a review of the literature. Journal of Advanced Nursing. 43: 6270.

Potter, P.A. dan Perry, A.G. (1999). Basic Nursing: A critical thinking approach. 4 th. St. Louis: Mosby.

Wardani, I GAK. (1997). Modul 10 Menulis Laporan Penelitian. Jakarta: Penerbit Universitas Terbuka.

Wardani, I GAK, Wihardit, Nasoetion. (2006). Penelitian Tindakan Kelas. Jakarta: Penerbit Universitas Terbuka.

Williams, K., \& Williams, C. (2011). Five key ingredients for improving motivation. Research in Higher Education Journal, 11. http://aabri.com/manuscripts/1 1834 .pdf 